\title{
ANALISIS PENGARUH PENGELUARAN PEMERINTAH DAN INVESTASI SWASTA TERHADAP PERTUMBUHAN EKONOMI DI KOTA BITUNG
}

\author{
Lisa Irma Abigael Lebang, Debby Ch. Rotinsulu, George M.V.Kawung \\ Fakultas Ekonomi dan Binis, Magister Ilmu Ekonomi dan Bisnis \\ Universitas Sam Ratulangi, Manado
}

\begin{abstract}
ABSTRAK
Kota Bitung merupakan daerah di Sulawesi Utara yang memiliki banyak industri yang dikelola oleh pihak swasta. Industri perikanan dan minyak kelapa merupakan industri utama di Kota Bitung. Hal ini merupakan kenyataan bahwa investasi swasta di Kota Bitung cukup besar. Kondisi ini tentunya memberikan dampak bagi perekonomian Kota Bitung antara lain, dengan kehadiran industri-industri tersebut telah mampu menyerap tenaga kerja dan mengurangi pengangguran di Kota Bitung. Hal yang lebih penting juga untuk diketahui adalah tentang pengaruh investasi swasta di Kota Bitung terhadap pertumbuhan ekonomi. Tujuan dari penelitian ini untuk menganalisis bagaimana pengaruh pengeluaran pemerintah, investasi swasta terhadap pertumbuhan ekonomi Kota Bitung. Teknik analisis yang digunakan Ordinary Least Square (OLS). Hasil penelitian menunjukan bahwa pengeluran pemerintah tidak memiliki pengaruh terhadap pertumbuhan ekonomi Kota Bitung sedangkan investasi swasta tidak memiliki pengaruh terhadap pertumbuhan ekonomi Kota Bitung dan secara bersama-sama pengeluaran pemerintah dan investasi swasta di Kota Bitung.
\end{abstract}

\section{Kata Kunci : Pengeluaran Pemerintah, Investasi Swata, Pertumbuhan Ekonomi}

\begin{abstract}
Bitung City is a region in North Sulawesi that has many industries managed by private parties. The fishery and coconut oil industry is the main industry in Bitung City. This is a fact that private investment in Bitung City is quite large. This condition certainly has an impact on the economy of Bitung City, among others, with the presence of these industries have been able to absorb labor and reduce unemployment in the city of Bitung. It is also important to know about the influence of private investment in Bitung City on economic growth. The purpose of this study is to analyze how the influence of government spending, private investment on the economic growth of Bitung City. Analysis technique used Ordinary Least Square (OLS). The result of the research shows that government expenditure has no influence on Bitung City's economic growth while private investment does not have influence to economic growth of Bitung City and jointly government expenditure and private investment in Bitung City.
\end{abstract}

Keyword : Government spending, Private investment, Economic Growth 


\section{PENDAHULUAN}

\section{Latar Belakang}

Pembangunan merupakan suatu proses perbaikan atau kemajuan dengan melakukan upaya ke arah perubahan yang lebih baik. Perubahan yang dimaksud adalah mencakup seluruh sistem yang ada dalam suatu wilayah atau negara seperti sistem politik, ekonomi, infrastruktur, pertahanan, pendidikan dan teknologi, kelembagaan serta budaya.

Pembangunan ekonomi suatu daerah pada hakekatnya ialah suatu rangkaian kegiatan yang dilaksanakan secara sadar dan terus menerus untuk mewujudkan keadaan yang lebih baik secara bersama-sama dan berkesinambungan. Dalam kerangka itu, pembangunan ekonomi juga untuk memacu pemerataan pembangunan dan hasil-hasilnya dalam rangka meningkatkan kesejahteraan rakyat secara adil dan merata. Salah satu tolok ukur penting dalam menentukan keberhasilan pembangunan ekonomi adalah pertumbuhan ekonomi yang menggambarkan suatu dampak nyata dari kebijakan pembangunan yang dilaksanakan.

Selain itu peranan pemerintah juga penting terutama dalam hal merencanakan pertumbuhan ekonomi suatu negara dan dalam menghimpun dana untuk keperluan investasi agar pertumbuhan ekonomi dapat meningkat. Peran pemerintah dalam meningkatkan pembangunan ekonomi serta memacu pertumbuhan ekonomi terutama di negara yang sedang berkembang dilakukan melalui kebijakan moneter dan kebijakan fiskal. Kebijakan moneter memainkan peranan penting dalam mempercepat pembangunan dengan mempengaruhi biaya dan tersedianya kredit, dengan mengendalikan inflasi, dan menjaga keseimbangan neraca pembayaran.

Kota Bitung merupakan daerah di Sulawesi Utara yang memiliki banyak industri yang dikelola oleh pihak swasta. Industri perikanan dan minyak kelapa merupakan industri utama di Kota Bitung (BPS : 2016) . Hal ini merupakan kenyataan bahwa investasi swasta di Kota Bitung cukup besar. Kondisi ini tentunya memberikan dampak bagi perekonomian Kota Bitung antara lain, dengan kehadiran industri-industri tersebut telah mampu menyerap tenaga kerja dan mengurangi pengangguran di Kota Bitung. Hal yang lebih penting juga untuk diketahui adalah tentang pengaruh investasi swasta di Kota Bitung terhadap pertumbuhan ekonomi.

Realisasi Belanja dalam APBD merupakan kenyataan mengenai pengeluaran pemerintah Kota Bitung setiap tahunnya. Dana yang bersumber dari pemerintah pusat berupa dana perimbangan (Dana Alokasi Umum, Dana Alokasi Khusus, dan Dana Bagi Hasil) serta Pendapatan Asli Daerah Kota Bitung merupakan sumber pembelanjaan dan pengeluaran bagi pemerintah daerah amanah Undang-Undang No.32 tentang Pemerintahan Daerah dan UU No.33 tahun 2004 tentang Perimbangan Keuangan antara Pemerintah Pusat dan Pemerintah Daerah. Oleh karena itu berdasarkan semangat otonomi daerah dalam menjalankan amanat Undang Undang maka sudah seharusnya pemerintah daerah bijak dalam pengelolaan keuangan daerah sebab dengan adanya dana dalam jumlah besar yang diberikan oleh pemerintah pusat yang ditunjang oleh PAD maka sudah seharusnya setiap pengeluaran dan belanja yang dikeluarkan oleh pemerintah daerah termasuk pemerintah Kota Bitung mampu memberikan dampak bagi perekonomian terutama terhadap pertumbuhan ekonomi di Kota Bitung.

\section{Tujuan Penelitian}

Untuk mengetahui pengaruh pemerintah dan investasi swasta terhadap pertumbuhan ekonomi di Kota bitung. 


\section{Landasan Teori}

\section{Pengertian dan unsur-unsur APBD}

Anggaran daerah merupakan rencana keuangan yang menjadi dasar dalam pelaksanaan pelayanan publik. Di Indonesia, dokumen anggaran daerah disebut Anggaran Pendapatan dan Belanja Daerah (APBD), baik untuk provinsi maupun kabupaten dan kota. Anggaran Pendapatan dan Belanja Daerah (APBD) pada hakekatnya merupakan salah satu instrumen kebijakan yang dipakai sebagai alat untuk meningkatkan pelayanan umum dan kesejahteraan masyarakat di suatu daerah. Di dalam APBD tercermin kebutuhan masyarakat dengan memperhatikan potensi dan sumber-sumber kekayaan daerah (UU Keuangan Negara, 2002).

\section{Belanja Daerah}

Pendapatan daerah yang diperoleh baik dari pendapatan asli daerah maupun dari dana perimbangan tentunya digunakan oleh pemerintah daerah untuk membiayai belanja daerah. Menurut Undang-Undang Nomor 32 Tahun 2004 tentang Pemerintah Daerah, belanja daerah adalah semua kewajiban daerah yang diakui sebagai pengurang nilai kekayaan bersih dalam periode tahun anggaran yang bersangkutan.

Di dalam ketentuan umum Undang-Undang Nomor 17 Tahun 2003 pada Pasal 1 ayat (16) disebutkan bahwa belanja daerah adalah kewajiban pemerintah daerah yang diakui sebagai pengurang nilai kekayaan bersih. Selanjutnya dalam Peraturan Pemerintah Nomor 58 Tahun 2005 Pasal 20 ayat (3) menyebutkan bahwa Belanja Daerah sebagaimana dimaksud pada ayat (1) huruf (a) meliputi semua pengeluaran dari rekening kas umum daerah yang mengurangi ekuitas dana lancar, yang merupakan kewajiban daerah dalam satu tahun anggaran yang tidak akan diperoleh pembayarannya kembali oleh daerah.

Belanja adalah semua pengeluaran pemerintah daerah pada suatu periode anggaran. Belanja daerah menurut kelompok belanja berdasarkan Permendagri 13/ 2006 terdiri atas belanja tidak langsung dan belanja langsung. Kelompok belanja tidak langsung merupakan belanja yang dianggarkan tidak terkait secara langsung dengan pelaksanaan program dan kegiatan. Kelompok belanja langsung merupakan belanja yang dianggarkan terkait secara langsung dengan pelaksanaan program dan kegiatan.

1. Belanja tak langsung adalah bagian belanja yang dianggarkan tidak terkait langsung dengan pelaksanaan program seperti belanja pegawai berupa gaji dan tunjangan yang telah ditetapkan undang-undang, belanja bunga, belanja hibah, belanja bantuan sosial, belanja bagi hasil kepada provinsi/kabupaten/kota dan pemerintah desa, belanja bantuan keuangan dan belanja tak tersangka.

2. Belanja langsung adalah bagian belanja yang dianggarkan terkait langsung dengan pelaksanaan program seperti belanja pegawai, belanja barang dan jasa, serta belanja modal untuk melaksanakan program dan kegiatan pemerintah daerah dan Telah dianggarkan oleh pemerintah daerah.

\section{Teori Investasi}

Menurut Boediono (2001 : 40-41) investasi adalah pengeluaran yang dilakukan oleh produsen (swasta) untuk pembelian barang-barang dan jasa untuk tujuan penanaman modal yakni untuk menambahan stok di gudang atau perluasan pabrik. Sektor perusahaan membeli barang bukan untuk tujuan konsumsi seperti yang sering dilakukan oleh sektor rumah tangga, tetapi untuk tujuan investasi. Ini berarti bahwa barang-barang tersebut dibeli dengan harapan 
untuk menghasilkan keuntungan di kemudian hari. Ini selanjutnya berarti bahwa pertimbanganpertimbangan yang diambil oleh perusahaan dalam memutuskan apakah membeli atau tidak membeli barang-barang dan jasa adalah harapan dari pengusaha akan kemungkinan keuntungan yang bisa di peroleh dengan menjual kemudian barang-barang tersebut atau menggunakannya untuk proses produksi. Arahan keuntungan inilah yang merupakan faktor utama dalam keputusan tersebut.

\section{Teori Pertumbuhan Ekonomi}

Pertumbuhan ekonomi adalah suatu kondisi terjadinya perkembangan Gross National Product (GNP) potensial yang mencerminkan adanya pertumbuhan output per kapita dan meningkatnya standar hidup masyarakat. (Murni, 2006 : 173). Pertumbuhan ekonomi sering dijadikan indikator utama karena memberikan implikasi pada kinerja perekonomian makro yang lain.

Widodo (2006 : 81-82) menjelaskan bahwa semakin tinggi pertumbuhan ekonomi suatu daerah menunjukkan semakin berkembangnya aktivitas perekonomian, baik aktivitas produksi,konsumsi, investasi, maupun perdagangan di daerah tersebut yang kemudian berdampak pada penyerapan tenaga kerja. Terdapat empat sumber pertumbuhan ekonomi :

1. Sumber daya alam. Penemuan sumber daya alam yang baru akan meningkatkan kemampuan perekonomian menghasilkan output.

2. Pertumbuhan penduduk (angkatan kerja). Pertumbuhan penduduk (angkatan kerja) disertai dengan lapangan pekerjaan akan dapat meningkatkan output perekonomian. Pertumbuhan penduduk disini juga mencakup produktivitas tenaga kerja itu sendiri.

3. Akumulasi capital. Pemilik modal akan memiliki kesempatan untuk melakukan investasi kembali (reinvest) sehingga akan meningkatkan output perekonomian.

\section{METODE PENELITIAN}

\section{Data dan Sumber Data}

Data yang digunakan dalam penelitian ini adalah data sekunder time series tahun 20062015 yang bersumber dari Badan Pusat Statistik (BPS) Sulawesi Utara dan Dinas Pendapatan Daerah (DISPENDA) Kota Bitung.

\section{Metode Pengumpulan Data}

Metode pengumpulan data yang digunakan dalam penelitian ini adalah metode dokumentasi data dimana peneliti melakukan pengumpulan data dengan mendatangi langsung sumber data dan mengumpulkan data sekunder yang telah ada di instansi terkait.

\section{Definisi Operasional dan Pengukuran Variabel}

Variabel yang digunakan dalam penelitian ini adalah sebagai berikut :

- Pengeluaran pemerintah ialah pengeluaran yang dilakukan oleh pemerintah Kota Bitung yang merupakan realisasi dari belanja APBD setiap tahunnya yang diukur dalam satuan rupiah per tahun.

- Investasi Swasta ialah besarnya nilai investasi sektor industri menurut kelompok industri yang ada di Kota Bitung, yang diukur dalam satuan rupiah per tahun. 
- Pertumbuhan Ekonomi ialah pertumbuhan dari nilai riil perekonomian Kota Bitung yakni pertumbuhan PDRB Riil (Atas Dasar Harga Konstan) setiap tahunnya yang diukur dalam satuan persen /tahun.

\section{Metode Analisis Data}

Metode analisis yang digunakan dalam penelitian ini adalah :

1. Analisis Deskriptif ; metode ini berupa metode analisa tabel yang bertujuan untuk mengkaji dan menganalisa perkembangan yang terjadi dalam perekonomian di Kota Bitung secara umum dan lebih khusus lagi mengenai perkembangan pengeluaran pemerintah, investasi swasta, serta pertumbuhan ekonomi.

2. Analisis Statistik Inferensia; Analisis statistik yang digunakan adalah analisis regresi berganda dengan rumus sebagai berikut :

a. $\quad \mathbf{Y}=\boldsymbol{\beta} \mathbf{0}+\boldsymbol{\beta} \mathbf{1 X 1}+\boldsymbol{\beta} \mathbf{2} \times \mathbf{2}+\mathbf{e}$; dimana :

$\mathrm{Y}=$ Pertumbuhan Ekonomi (Variabel Terikat)

$\beta \mathrm{o}=$ Konstanta

$\beta 1$ dan $\beta 2=$ Koefisien Regresi

$\mathrm{X} 1$ = Pengeluaran pemerintah $($ Variabel Bebas 1$)$

$\mathrm{X} 2$ = Investasi Swasta (Variabel Bebas 2)

$\mathrm{e}=$ Parameter Pengganggu

\section{Hipotesis}

Hipotesis dari penelitian ini diduga bahwa:

- Pengeluaran Pemerintah memiliki pengaruh terhadap Pertumbuhan Ekonomi di Kota Bitung.

- Investasi Swasta memiliki pengaruh terhadap Pertumbuhan Ekonomi di Kota Bitung.

- Pengeluaran Pemerintah dan Investasi Swasta secara bersama-sama memiliki pengaruh terhadap pertumbuhan ekonomi di Kota Bitung.

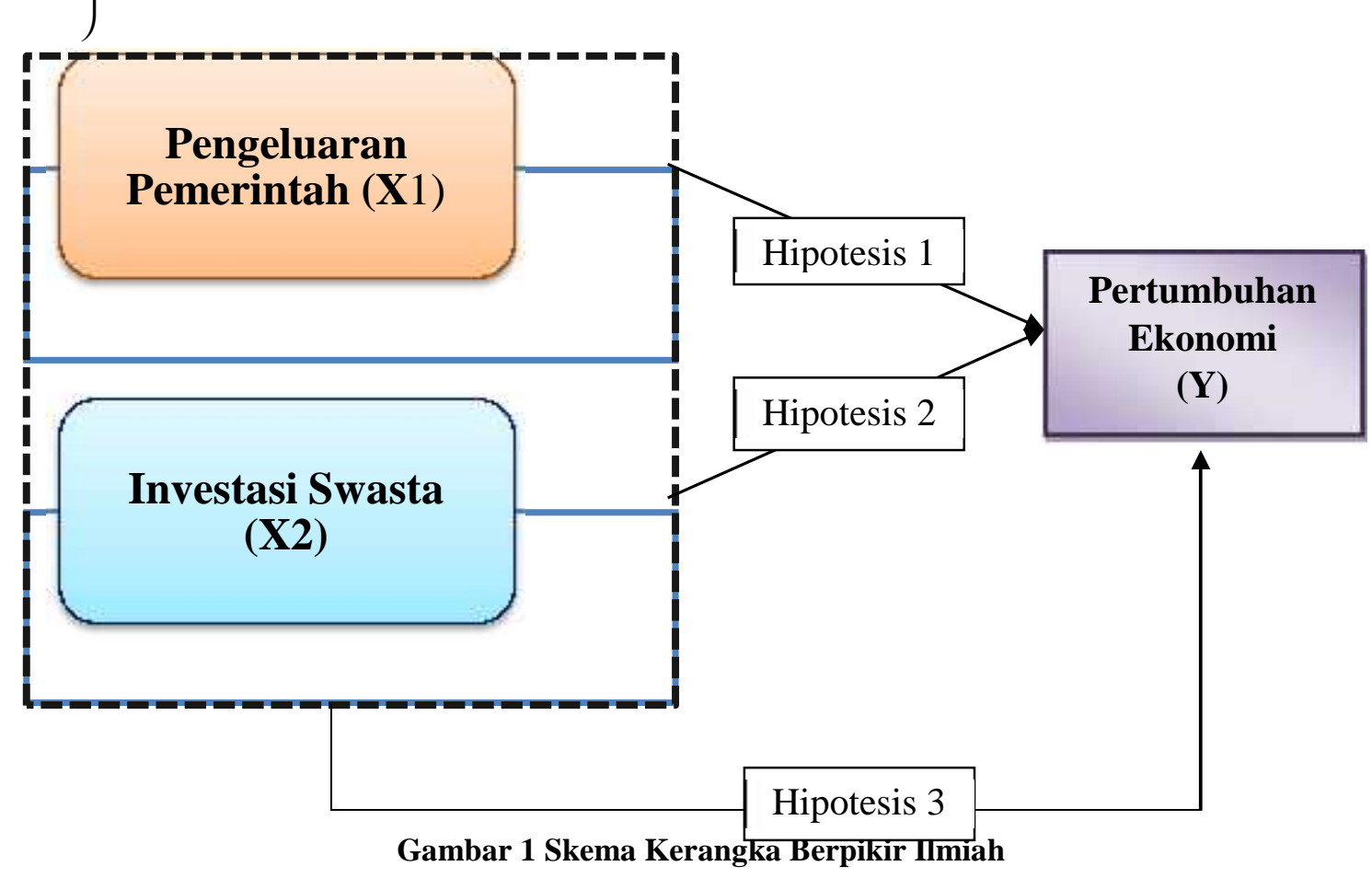




\section{HASIL PENELITIAN DAN PEMBAHASAN}

\section{Uji Asumsi Klasik}

Uji asumsi klasik dalam penelitian ini menggunakan bantuan Software SPSS 17 hasilnya adalah sebagai berikut :

a.

Uji Auto Korelasi

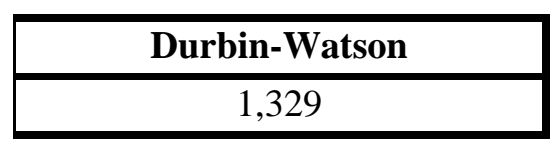

Hasil uji autokorelasi terhadap variabel-variabel penelitian ini menunjukkan angka Durbin Watson sebesar (DW) 1,329. Karena nilai DW adalah $-2<1,329<2$ maka tidak terjadi autokorelasi dalam variabel penelitian ini.

b. Uji Multikolinieritas

\begin{tabular}{|l|c|c|}
\hline \multirow{2}{*}{ Model } & \multicolumn{2}{|c|}{ Collinearity Statistics } \\
\cline { 2 - 3 } & Tolerance & VIF \\
\hline (Constant) & 0,185 & 5,413 \\
Pengeluaran Pemerintah & 0,185 & 5,413 \\
Investasi Swasta & & \\
\hline
\end{tabular}

Hasil uji multikolinieritas menunjukkan bahwa nilai VIF dari variabel pengeluaran pemerintah,ah dan Jumlah penduduk adalah lebih kecil dari 10. Hal ini menunjukkan bahwa tidak terjadi gejala multikolineritas di dalam variabel penelitian ini.

c. Uji Heteroskedastisitas

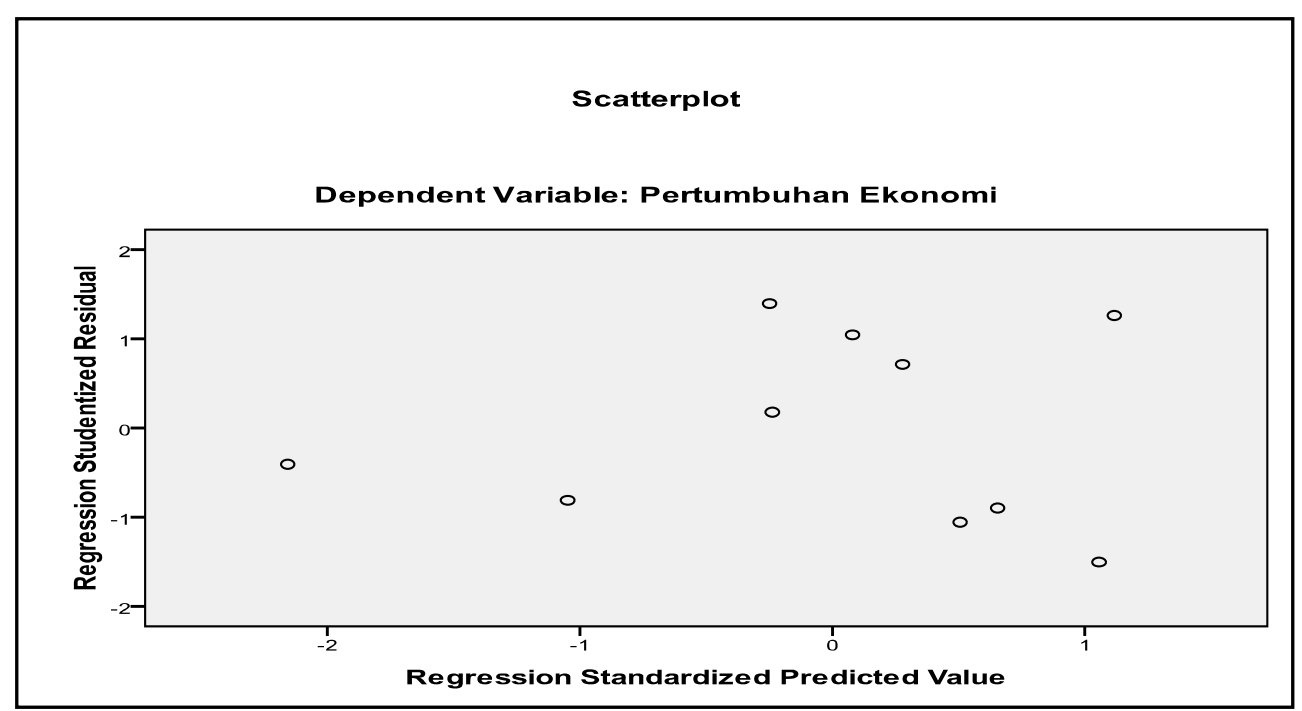


Hasil uji Heteroskedastisias memperlihatkan sebaran plot dalam scatterplot tidak beraturan atau tidak membentuk suatu pola tertentu yang rapi dan teratur. Oleh karena itu berdasarkan hal ini maka di dalam penelitian ini tidak terdapat gejala homokedastisitas dalam variabel penelitian.

\section{Uji Asumsi Normal}

Uji normalitas data bertujuan untuk menguji data-data tentang variabel yang digunakan dalam penelitian ini apakah sudah tersebar secara normal atau tidak. Sebelum digunakan dalam model regresi berganda maka variabel-varibel penelitian perlu di uji kenormalan datanya. Asumsi yang digunakan adalah bahwa data peneltian adalah data yang tersebar secara normal atau tersebar mendekati sumbu regresi. Uji normalitas data dalam penelitian ini menggunakan Test Kolmogorov-Smirnov dengan Software Program SPSS 17. Hasil uji normalitas data adalah sebagai berikut :

One-Sample Kolmogorov-Smirnov Test

\begin{tabular}{|ll|r|r|r|}
\hline & & $\begin{array}{c}\text { Pertumbuhan } \\
\text { Ekonomi }\end{array}$ & $\begin{array}{c}\text { Pengeluaran } \\
\text { Pemerintah }\end{array}$ & Investasi Swasta \\
\hline $\mathrm{N}$ & & 10 & 10 & 10 \\
Normal Parameters $\mathrm{a}, \mathrm{b}$ & Mean & 190.80 & $2,687.40$ & $2,347.50$ \\
& Std. Deviation & 18.146 & 34.050 & 350.500 \\
Most Extreme & Absolute & .183 & .095 & .300 \\
Differences & Positive & .125 & .081 & .300 \\
& Negative & -.183 & -.095 & -.197 \\
Kolmogorov-Smirnov Z & & .579 & .299 & .947 \\
Asymp. Sig. (2-tailed) & & .891 & 1.000 & .331 \\
\hline
\end{tabular}

Hasil uji normalitas data menunjukkan bahwa nilai Asymp. Sig. (2-tailed) untuk variabel Pengeluaran Pemerintah adalah sebesar 1,00, variabel Investasi Swasta sebesar 0,331 dan variabel Pertumbuhan Ekonomi sebesar 0,891. Ketiga variabel memiliki nilai Asymp. Sig. (2tailed) lebih besar dari 0,05 maka dapat disimpulkan bahwa data yang digunakan dalam penelitian ini tersebar secara normal.

\section{Hasil Uji Regresi Berganda dan Pengaruh Secara Parsial}

\begin{tabular}{|l|r|c|r|r|}
\hline \multirow{2}{*}{ Model } & \multicolumn{2}{|c|}{$\begin{array}{c}\text { Unstandardized } \\
\text { Coefficients }\end{array}$} & $\begin{array}{c}\text { Standardized } \\
\text { Coefficients }\end{array}$ & \multirow{2}{*}{ t } \\
\cline { 2 - 4 } & \multicolumn{1}{|c|}{ B } & \multicolumn{1}{c|}{ Std. Error } & \multicolumn{1}{c|}{ Beta } & \\
\hline (Constant) & $-1457,392$ & 950,606 & - & 1,533 \\
Pengeluaran Pemerintah & 0,653 & 0,383 & 1,225 & 1,705 \\
Investasi Swasta & $-0,045$ & 0,037 & $-0,869$ & $-1,210$ \\
& & & & \\
\hline
\end{tabular}


Persamaan Regresi $\quad \hat{Y}=-1457,392+0,653 P$ P - 0,045IS. Interpretasi dari persamaan regresi ini adalah sebagai berikut :

- Nilai konstanta -1457,392 mengandung arti jika pengeluaran pemerintah dan investasi swasta bernilai nol pertumbuhan ekonomi adalah sebesar -1457,392\%.

- Nilai koefisien regresi untuk Pengeluaran Pemerintah sebesar 0,653 mengandung arti jika pengeluaran pemerintah meningkat sebesar 1 persen maka pertumbuhan ekonomi juga akan meningkat sebesar 0,653 persen.

- Nilai koefisien regresi untuk Investasi Swasta sebesar -0,045 mengandung arti bahwa jika investasi swasta meningkat sebesar 1 persen maka pertumbuhan ekonomi akan mengalami penurunan sebesar 0,045 persen.

Pengaruh variabel bebas terhadap variabel terikat secara parsial atau sendiri-sendiri dapat dilihat dalam nilai uji $\mathrm{t}_{\text {hitung }}$ kemudian dibandingkan dengan nilai $\mathrm{t}$ tabel. Hasilnya adalah sebagai berikut :

- $t_{\text {hitung }}$ untuk variabel Pengeluaran Pemerintah adalah 1,705 sedangkan $t_{\text {tabel }}\left(\alpha_{0,05 / 2 ; 10-3}\right.$ menjadi $\alpha 0,025$; 7) memiliki nilai t tabel sebesar : 2,306 Hasil ini menunjukan bahwa $\mathrm{t}_{\text {hitung }}<\mathrm{t}$ tabel. Artinya secara parsial pengeluaran pemerintah tidak memiliki pengaruh terhadap pertumbuhan ekonomi di Kota Bitung.

- $\mathrm{t}_{\text {hitung }}$ untuk variabel Investasi Swasta adalah $-1,210$ sedangkan $\mathrm{t}_{\text {tabel }}\left(\alpha_{0,05 / 2} ; 10-3\right.$ menjadi $\alpha 0,025$; 7) memiliki nilai $\mathrm{t}$ tabel sebesar : 2,306 Hasil ini menunjukan bahwa $\mathrm{t}_{\text {hitung }}<\mathrm{t}$ tabel. Artinya secara parsial Investasi tidak memiliki pengaruh terhadap pertumbuhan ekonomi di Kota Bitung.

\section{Pengaruh Variabel Bebas terhadap Variabel Terikat secara Bersama-sama atau Simultan}

Pengaruh variabel Pengeluaran Pemerintah dan Investasi Swasta terhadap pertumbuhan ekonomi di Kota Bitung dapat dilihat dalam hasil uji $\mathrm{F}_{\text {hitung }}$ kemudian dibandingkan dengan nilai F tabel. Hasilnya adalah sebagai berikut :

ANOVA

\begin{tabular}{|c|c|c|c|c|c|c|}
\hline & Model & $\begin{array}{l}\text { Sum of } \\
\text { Squares }\end{array}$ & df & Mean Square & $\mathrm{F}$ & Sig. \\
\hline \multirow[t]{3}{*}{1} & Regression & 986.575 & 2 & 493.287 & \multirow[t]{3}{*}{1.747} & \multirow[t]{3}{*}{$.242^{\mathrm{a}}$} \\
\hline & Residual & 1977.025 & 7 & 282.432 & & \\
\hline & Total & 2963.600 & 9 & & & \\
\hline
\end{tabular}

a. Predictors: (Constant), Investasi Swasta, Pengeluaran Pemerintah

b. Dependent Variable: Pertumbuhan Ekonomi

Berdasarkan tabel ANOVA tersebut diatas maka dapat dianalisa sebagai berikut :

- Nilai $F_{\text {hitung }}$ adalah sebesar 1,747

- Nilai Ftabel untuk 2 variabel bebas $(\mathrm{k}=2)$ dengan $n-k(10-2)$ atau 2 variabel bebas dan $n$ $=8$ adalah 4,46

- Nilai $F_{\text {hitung }}(1,747)<$ Nilai $F$ tabel $(4,46)$, dengan demikian maka secara bersama-sama atau simultan maka variabel Pengeluaran Pemerintah dan Investasi Swasta, tidak memiliki pengaruh terhadap Pertumbuhan Ekonomi di Kota Bitung. 


\section{Korelasi antara Variabel Bebas Dengan Variabel Terikat}

Korelasi atau keeratan hubungan antara variabel bebas dengan variabel terikat dapat dilihat dalam besarnya hasil uji korelasi yakni uji R :

\begin{tabular}{|c|c|c|c|c|}
\hline Model & $\mathbf{R}$ & R Square & $\begin{array}{c}\text { Adjusted R } \\
\text { Square }\end{array}$ & $\begin{array}{c}\text { Std. Error of } \\
\text { the Estimate }\end{array}$ \\
\hline $\mathbf{1}$ & $0,577^{\mathrm{a}}$ & 0,333 & 0.142 & 16,806 \\
\hline
\end{tabular}

Hasil uji R menunjukkan bahwa keeratan hubungan antara Pengeluaran pemerintah dan Investasi Swasta sebagai variabel bebas dalam penelitian ini dengan pertumbuhan ekonomi sebagai variabel terikat adalah sebesar $57,7 \%$. Hal ini berarti bahwa antara variabel bebas dengan variabel terikat terdapat hubungan yang kurang erat dan cenderung lemah.

\section{Kontribusi Variabel bebas terhadap Variabel Terikat}

Kontribusi atau determinasi variabel bebas terhadap variabel terikat dalam penelitian ini dpat diliaht dalam uji determinan ( $R$ Square atau $\mathrm{R}^{2}$ ). Hasil yang tercantum dalam tabel diatas menunjukkan bahwa nilai $\mathrm{R}$ Square adalah sebesar 0,333 atau 33,3\%. Hal ini berarti bahwa kontribusi pengeluaran pemerintah dan investasi swasta terhadap pertumbuhan ekonomi di Kota Bitung adalah sebesar 33,3\% sedangkan sisanya sebesar 63,7\% disumbangkan oleh variabel lain yang tidak dikaji dalam penelitian ini.

\section{KESIMPULAN DAN SARAN}

\section{Kesimpulan}

Berdasarkan hasil penelitian dan pembahasan maka dapat ditarik kesimpulan sebagai berikut :

- Pengeluaran pemerintah Kota Bitung selama kurun waktu penelitian ini ternyata tidak memiliki pengaruh terhadap pertumbuhan ekonomi

- Investasi Swasta selama kurun waktu penelitian ini ternayat tidak memiliki pengaruh terhadap pertumbuhan ekonomi di kota Bitung.

- Secara bersama-sama pengeluaran pemerintah dan investasi di kota Bitung tidak memiliki pengaruh terhadap pertumbuhan ekonomi di Kota Bitung.

\section{Saran}

Pemerintah perlu memperhatikan pos-pos pengeluaran atau belanja pemerintah Kota Bitung agar dapat lebih terpakai untuk menggenjot perekonomian dan diarahkan ke pos-pos pengeluaran yang benar-benar memberikan nilai tambah yang nyata bagi perekonomian sehingga mampu mempengarruhi pertumbuhan ekonomi. Selain itu investasi swasta juga perlu diperhatikan agar lebih memebrikan dampak yang lebih besar terhadap perekonomian dan pertumbuhan ekonomi di Kota Bitung. 


\section{DAFTAR PUSTAKA}

[1] Adhisasmita,2005, Analisis Kesenjangan Pembangunan Regional Indonesia 1992-2004: Jurnal Ekonomi Pembangunan Kajian Ekonomi Negara Berkembang, Volume 9 Nomor 2 Halaman 129 -142.

[2] Anasmen, 2009, Pengaruh Belanja Modal Pemerintah Terhadap Pertumbuhan Ekonomi di Sumatera Barat (2000-2006), Tesis, Program Magister Perencanaan dan Kebijakan Publik, Universitas Indonesia, Jakarta.

[3] Antasari, Merri dan Soleh, Ahmad, 2014, Pengaruh Pengeluaran Pemerintah Terhadap Pertumbuhan Ekonomi di Provinsi Bengkulu , Ekombis Review, Universitas Bengkulu

[4] Boediono, 2001, Teori Pertumbuhan Ekonomi, BPFE UGM, Yogyakarta

[5] Murni, Asfiah (2006), Ekonomika Makro, Penerbit PT.Rafika Aditama, Bandung.

[6] Undang-Undang No.32 tentang Pemerintahan Daerah

[7] UU No.33 tahun 2004 tentang Perimbangan Keuangan antara Pemerintah Pusat dan Pemerintah Daerah 